\title{
EFFECT OF PROTEIN TYPE AND SUGAR TYPE ON CHOCHOLATE PROPERTIES
}

\author{
Muhammad Rifqi \\ Department of Food Technology and Nutrition, \\ Faculty of Halal Food Science, Djuanda University \\ E-mail: rifqimuhammadsuryana@gmail.com
}

\begin{abstract}
This research aimed to investigate the effect of protein types (soy milk powder and skim milk powder) and sugar types (stevia and sucrose) on sensory properties of chocolate candy. The appropriate level of protein and sugar were also expected. The research performed using factorial randomized block design (RBD) with three replications. Factors namely ratio of protein type (soy milk powder, skim milk powder) and the ratio of sugar type (sucrose, stevia) were applied. Organoleptic response variables included taste, flavor, texture, and aftertaste were conducted using a hedonic test on 30 panelists. The results indicated that chocolate candy made from the ratio of soy milk with skim milk 0:1 and the ratio of sucrose and stevia of 1:1 gave the highest value of the organoleptic test. Proximate analysis showed the chocolate candy $11.05 \%$ fat, $13.44 \%$ protein, $25.28 \%$ carbohydrate, and water content of $1.17 \%$ and has a toughness test value of $1.23 \mathrm{~mm} / \mathrm{sec} / 100 \mathrm{gram}$. This study revealed that alternative sugar (stevia) can be used in chocolate candy making and is expected to reduce calories contained on chocolate candy.
\end{abstract}

Keywords: chocolate candy, soy milk powder, skim milk powder, stevia, sucrose

\section{INTRODUCTION}

Cocoa is one of the economic plantation crops that contribute to Indonesia's gross domestic product (GDP). Cocoa can be processed into cocoa powder, cocoa butter, or cocoa paste which are the raw materials for chocolate making. Cocoa also contains polyphenols and flavonoids which act as antioxidants and provide health benefits. The content of methylxanthine (caffeine, theobromine, and theophylline) in the cocoa product is a stimulant of the central nervous system and strengthens the heart activity (Minifie, 2012). Cacao utilization is expected to improve the value-added of the crop.

Chocolate candy is one of the cacao products that very popular among children because of its sweet taste. The ingredients namely cocoa fat, cocoa powder, milk powder, sugar, and lecithin (Minifie, 2012). Children's preference for food tends to combine sugar and fat derived from cookies, chocolate candies, and ice cream. Study linked diet with high sugar and fat content increasing the prevalence of childhood obesity (Drewnowski, 1989). With the current health emphasis on low-sugar diets, there is a need for basic research on the sensory and hedonics aspect of sugar or sugar substitute and the human preferences for low-sugar containing food.

Reducing sucrose with sweeteners in chocolate candy can largely reduce the calorie content in chocolate candy. According to Verruma-Bernardi (2014), there is a growing interest in low-calorie alternatives to sucrose and recent publications have shown a strong increase in the attention to extracts of the Stevia plant for its sweetening qualities. 
Stevia has the most sweetness and the least off-taste to human-raters. It provides zero calories and has a clean, sweet taste with no significant undesirable taste characteristics. European Union, Japan, China, Australia, Brazil, and the U.S are permitting the use of stevia as sweeteners and classified as generally recognized as safe (GRAS) for the general population, including children, people with diabetes, and women who are pregnant or nursing (Perez et al, 2016).

Milk is one of the most complex raw materials used by the food industry. Milk contains protein, fat, sugar, and minerals. Milk fat along cocoa fat affects the rheological properties of fluid chocolate, release from the mould, snap, gloss, prevention of bloom, melting properties, and flavor release (Haylock and Dodds, 1999). However, since customer interest on functional food increases, there is also increasing consumption of soy protein due to soy protein's ability to reduce serum cholesterol-lowering the potential for insulin resistance in diabetes (Bordy, 2002). Bordi (2008) researched added soy protein isolate in chocolate peanut butter candy to reduce fat content. The result showed panelist liking on overall flavor was not found to be significantly different between the soy enhanced and control candy products. Formulating these snack products to a healthier level raises the feasibility of reducing fat in the diet of youths.

High sucrose and high fat snack receive great attention due to health-related issues. Substituting sucrose with low-calorie sweeteners might be an alternative to reduce sucrose and fat consumption. The objective of this study was to evaluate the preference of chocolate candy using sucrose and stevia as sweetener and soy milk and skim milk as a fat replacer.

\section{MATERIALS AND METHODS Materials}

Cocoa powder, cocoa fat, soy milk powder, skim milk, and sucrose were purchased from the local grocery store (PD Kijang Mas Bandung, West Java), stevia sugar, purchased from Depok, and lecithin purchased from PT Brataco Chemical Bandung. Chemicals used for analysis were diethyl ether, petroleum ether, sulfuric acid, potassium iodide, sodium thiosulfate, HCN, sodium hydroxide, Luft schoorl reagent.

\section{Preliminary Research on Making Chocolate Candy}

Preliminary research was conducted to obtain the formula of chocolate candy made using different brand cocoa powder (Tulip Bergundi, Delfi, and Bensdrop) with the addition of cocoa fat, skim milk, sucrose, and lecithin. A hedonic test was carried out to investigate panelist acceptance of chocolate candy. Selected cocoa powder to be used in the main experiment was expected.

The preliminary research was done by making chocolate candy products using chocolate powder with several brands: Tulip Bergundi, Delfi, and Bensdrop. Furthermore, chocolate candy obtained was then performed organoleptic testing using a Hedonic scale that is transformed into a numerical scale. Panelists used were 30 people with the attributes assessed which were the taste, flavor, texture, and aftertaste, afterwards the chocolate powder that was selected are used in the main study. Also, the main ingredients used were performed chemical analysis, including analysis of fat content with the Soxhlet method, protein content with the method of kjedahl, and sugar level with the Luft Schoorl method (Sudarmadji, 2007). 


\section{Chocolate Candy Production}

Selected cocoa powder based on a hedonic test will be used in primary research. The fat source was obtained from soy milk and skim milk while the sugar source was obtained from sucrose and stevia. The ratio of soy milk and skim milk along with sucrose and stevia varied to get optimized chocolate candy characteristics to prefer by panelists. The design of experiment can be seen below.

\section{Experiment Description}

Preliminary experiments were carried out by making Chocolate Candy products by using a variety of cocoa powder with each cocoa powder brand which are Tulip Bergundi, Delfi, and Bensdrop, cocoa powder with the highest panelist acceptance was ex[ected. The description of the preliminary research experiment is as follows:

\section{Material Preparation}

The materials used in the manufacture of Chocolate Candy products are several brands of cocoa powder: Tulip Bergundi, Delfi, and Bensdrop, cocoa butter, sucrose, skim milk, and lecithin. The materials that have been prepared are weighed in accordance with a predetermined basis.

\section{Mixing I}

Cocoa powder and cocoa butter were mixed to obtain cocoa liquor. Mixer used as a mixing device mixing carried out for 15 minutes at $60{ }^{\circ} \mathrm{C}$.

\section{Mixing II (conching)}

Mixing I results, sucrose, skim milk, and lecithin is mixed using an agitator at $60{ }^{\circ} \mathrm{C}$ for 8 hours.

\section{Tempering}

The batter as a result of mixing II was left for 20 minutes or until the batter has a temperature of $25^{\circ} \mathrm{C}$.

\section{Printing}

A batter of mixing II results was printed using a mold that has been provided, the batter has been printed.

\section{Cooling}

The batter that has been cooled in the cooling process, is again re-cooled at a temperature of $5^{\circ} \mathrm{C}$ for 10 minutes in the refrigerator.

\section{Main Research Description}

Procedures for making chocolate candy products on the main research are as follows:

\section{Material Preparation}

The raw material used in this research is selected cocoa powder, cocoa butter, soy milk powder, skim milk, sucrose, stevia sugar, and lecithin. The materials that have been prepared are weighed on a predetermined basis. 


\section{Mixing $\mathrm{I}$}

The selected cocoa powder and cocoa butter were mixed to obtain cocoa liquor. Mixer used as a mixing device mixing carried out for 15 minutes at $60^{\circ} \mathrm{C}$.

\section{Mixing II}

Mixing I results, sucrose, skim milk, and lecithin is mixed using an agitator at $60^{\circ} \mathrm{C}$ for 8 hours.

\section{Tempering}

The batter as a result of mixing II was left for 20 minutes or until the batter has a temperature of $25^{\circ} \mathrm{C}$.

\section{Printing}

The batter of mixing II results was printed using a mold that has been provided, the batter has been printed.

\section{Cooling}

The batter that has been cooled in the cooling process, is again re-cooled at a temperature of $5^{\circ} \mathrm{C}$ for $10 \mathrm{~min}$ in the refrigerator.

Parameter observed including proximate analysis (fat, protein, carbohydrate, water content). Physical analysis namely hardness by a penetrometer. Sensory analysis using a hedonic test to 30 panelists by scoring attributes of flavor, taste, texture, and aftertaste.

\section{Statistical Analysis}

Treatments and analyses were performed. Data were analyzed by ANOVA and Duncan's multiple range tests using Microsoft Office Excell for the determination of significant differences at $P<0.05$.

\section{RESULTS AND DISCUSSION}

The preliminary study carried out aimed to determine the cocoa powder type that most accepted by panelists. From the three brands used, the Tulip brand has the highest value of taste, flavor, texture, and aftertaste (Table 1).

Table. 1. Effect of Cocoa Powder brand on acceptance of chocolate candy

\begin{tabular}{|c|c|c|c|c|c|}
\hline \multirow{2}{*}{$\begin{array}{c}\text { Brand of cocoa } \\
\text { powder }\end{array}$} & \multicolumn{4}{|c|}{ Parameters } & \multirow{2}{*}{ Average } \\
\hline & Taste & Flavor & Texture & Aftertaste & \\
\hline Tulip (007) & 2.35 (b) & 2.31 (b) & 2.10 (c) & $2.20(b)$ & 2.24 \\
\hline Delfi (070) & 1.95 (a) & $2.00(a)$ & 2.09 (b) & $1.70(\mathrm{a})$ & 1.94 \\
\hline Bensdrop (023) & $2.023(a)$ & 2.25 (b) & $2.00(a)$ & $2.12(\mathrm{a})$ & 2.10 \\
\hline
\end{tabular}


The texture of chocolate candy made with Tulip bergundi cocoa powder has the highest value. According to Prasetya (2009), the texture is an important parameter in chocolate candy that good chocolate should have a smooth texture (smooth and buttery) which can melt gently and slowly in the mouth with complex and enjoyable flavors.

Chocolate is a dispersion of the particles that are blocked by fat crystals that act as an adhesive cement that physical properties and sensory of chocolate directly associated with the crystallization of cocoa butter (Haylock and Dodds, 1999). Protein, fat, and carbohydrate analysis conducted on Tulip Bergundi cocoa powder that can be seen in Table 2.

Table 2. Protein, fat, and carbohydrate content of Tulip Bergundi cocoa powder

\begin{tabular}{cc}
\hline Parameter & Result \\
\hline Fat & $10.01 \%$ \\
Protein & $10.48 \%$ \\
Carbohyrate & $52.09 \%$ \\
\hline
\end{tabular}

Natural cocoa powder is made from the pulp of chocolate or bittersweet chocolate block, by eliminating the fat down to 18-23\%. Cocoa powder contains energy of 298 kilocalories, 8 grams protein, 48.9 grams carbohydrates, 23.8 grams fat, 125 milligrams of calcium. Cocoa powder also contained as much as $30 \mathrm{IU}$ of vitamin $A, 0.12$ milligrams of vitamin B1, and 0 milligrams of vitamin C (Anonymous, 2001). Tulip Bergundi cocoa powder contains less fat and tastes bitter. Many people use this type of cocoa powder as ingredients to make a cake. Therefore milk and sugar need to be added for chocolate candy making. A further experiment was carried out by investigating the effect of soy milk and skim milk ratio of and sucrose and stevia sugar ratio on properties of chocolate candy (Table 3).

Table 3 showed there was an interaction between fat source ratio and sugar ratio on taste and flavor. However, no interaction occurred between fat source and sugar source on texture and aftertaste. This result was in agreement with Bordi (2002) that showed the use of soy protein did not change the organoleptic acceptance of chocolate candy. The texture of chocolate candy is affected by cocoa fat that determines the density of the chocolate.

Table 3. Effect of fat source ratio and sugar source ratio of taste and flavor of chocolate candy

\begin{tabular}{ccc}
\hline Sample & Taste & Flavor \\
\hline Soy milk : skim milk (1:0); stevia:sucrose (1:0) & 3.87 & 4.64 \\
Soy milk : skim milk (1:0); stevia:sucrose (1:1) & 4.18 & 4.13 \\
Soy milk : skim milk (1:0); stevia:sucrose (0:1) & 4.61 & 4.90 \\
Soy milk : skim milk (1:1); stevia:sucrose (1:0) & 4.38 & 4.48 \\
Soy milk: skim milk (1:1); stevia: sucrose (1:1) & 4.35 & 4.39 \\
Soy milk : skim milk (1:1); stevia:sucrose (0:1) & 5.89 & 5.49 \\
Soy milk : skim milk (0:1); stevia:sucrose (1:0) & 4.76 & 4.17 \\
Soy milk : skim milk (0:1); stevia:sucrose (1:1) & 4.83 & 5.88 \\
Soy milk : skim milk (0:1); stevia:sucrose (0:1) & 5.28 & 4.77 \\
\hline
\end{tabular}


Chocolate candy with soy milk: skim milk ratio of $1: 1$ and $0: 1$ with stevia sucrose of $0: 1$ have a higher score of taste and flavor. Since the two samples were not significantly different samples contain soy milk: skim milk ratio of $0: 1$ with stevia sucrose of 0:1 was chosen since the fat source only from skim milk. The flavor of chocolate candy is derived from the volatile compounds of cocoa fruit as well as from other materials namely milk and sugar. According to Prasetya (2009), chocolate flavor formed during the process of preparing the seeds, especially during fermentation, drying, roasting of cocoa beans. Chocolate flavor derived from hundreds of compounds including amino acids, peptides, sugars reducer, and quinone is group compounds of alcohol, ether, furan, triazole, acid, ether, ester, aldehyde, amine, pyrazine, and pyrrole. During the process of chocolate candy making, heating cause Maillard's reaction between the amino acid and reducing sugar in skim milk that also contributed to the flavor of chocolate candy. However, flavor and taste acceptance on chocolate candy contains soymilk was lower since soybean has a distinctive flavor (Erlita, 2002).

Chocolate has a bitter taste due to the alkaloid theobromine, caffeine, phenolic compounds, and free amino acids. The bitter taste of chocolate is often disconcerting with the astringent taste because people do not fully understand the different nature and taste between the two, especially tannins and polyphenols in chocolate as the most responsible component for the astringent and bitter taste (Armita, 2009). The addition of sugar in the manufacture of chocolate products intended to give the flavor of sweet to the chocolate products. The savory flavor found can be caused by the presence of fat content apart from the chocolate fat, but it can also come from soy milk and skim milk (Widiantara, 2004).

Proximate analysis performed on chocolate candy contain soy milk: skim milk ratio of 0: 1 with stevia sucrose of 0:1. The result can be seen in Table 4.

Table 4. Protein, fat, and carbohydrate content of chocolate candy

\begin{tabular}{cc}
\hline Parameter & Result (\%) \\
\hline Fat & 11.05 \\
Protein & 13.44 \\
Carbohydrate & 25.28 \\
Water content & 1.17 \\
\hline
\end{tabular}

Table 4 showed fat content in chocolate candy slightly higher than that in cocoa powder. Skim milk contains less fat that might contribute to the increased fat content. However, the fat source is mainly obtained from cocoa powder. The use of skim milk also increases the protein content in chocolate candy compare to that of cocoa powder. However, carbohydrate content in chocolate candy was lower than that of cacao powder. Most water in chocolate candy is attached to sugar that made it difficult to be evaporated. Low water content in chocolate candy is important since water availability might lead to hydrolytic rancidity.

Physical analysis of chocolate candy is performed by hardness test using a penetrometer and the result can be seen in Table 5. 
Table 5. Effect of fat source ratio and sugar source ratio of taste and flavor of chocolate candy

\begin{tabular}{cc}
\hline Sample & Hardness \\
\hline Soy milk : skim milk (1:0); stevia:sucrose (1:0) & 1.91 \\
Soy milk: skim milk (1:0); stevia: sucrose (1:1) & 1.69 \\
Soy milk : skim milk (1:0); stevia:sucrose (0:1) & 2.91 \\
Soy milk : skim milk (1:1); stevia:sucrose (1:0) & 2.62 \\
Soy milk: skim milk (1:1); stevia: sucrose (1:1) & 1.54 \\
Soy milk: skim milk (1:1); stevia: sucrose (0:1) & 7.28 \\
Soy milk : skim milk (0:1); stevia:sucrose (1:0) & 1.95 \\
Soy milk: skim milk (0:1); stevia: sucrose (1:1) & 2.03 \\
Soy milk : skim milk (0:1); stevia:sucrose (0:1) & 1.23 \\
\hline
\end{tabular}

Hardness is defined as the power or force needed to achieve the changes of shape. Analysis of toughness is performed because toughness is one of the most important quality criteria for the types of chocolate. A lower score indicated increasing in hardness. Although the fat source and sugar source did not affect the texture of chocolate candy, however, statistical analysis showed there was an interaction between the fat source and sugar source on the hardness of chocolate candy. According to Purnamasari (2011), sugar provides a density of the chocolate hardness texture of the chocolate that sugar addition increase chocolate hardness.

Cocoa powder is an important material in chocolate candy. The fat content in cocoa powder affects panelist acceptance on texture and flavor therefore the fat content should not be less than $10 \%$. The fat content also affected the hardness of chocolate candy. During chocolate candy making, fat from cocoa powder and milk is attributed to the texture and hardness of the chocolate candy. Therefore, the type of milk also important to obtain chocolate candy with accepted organoleptic characteristics by panelists.

\section{REFERENCES}

Armita, 2009, Tentang Cokelat, https://4rmita.wordpress.com/category/tentangcokelat/page/6/ (in Indonesia)

Astawan, M. (2011). Komposisi Gizi Rata-rata Cokelat Batangan. http://cybernews.cbn.net.id.diakses (in Indonesia)

Bordi, P. L., Lambert, C., Devitis, C. A., Chen, P. J., \& Conley, C. (2002). Sensory Comparison of a soy enhanced chocolate candy and a regular chocolate candy. Foodservice Research International, 13(3), 193-201.

Bordi, P. L., Cole, C., Borja, M., \& Conley, C. (2003). Sensory Comparison of a Soy Enhanced Chocolate Candy and Regular Candy by Children Age 9-16. Journal of Food Products Marketing, 9(2), 1-10.

Drewnowski, A. (1989). Sensory preferences for fat and sugar in adolescence and adult life.

Erlita, R. (2002). Suplementasi Tepung Kedelai Lemak Penuh (Full Fat Soy Flour) Hasil Pengeringan Silinder Pada Formula Roti Manis. http//Repository.ipb.ac.id. (in Indonesia) 
Haylock, S. J., \& Dodds, T. M. (1999). Ingredients from milk. Industrial chocolate manufacture and use, S.T.Beckett (ed). Pp : 137-152. Blackwell publishing, Chennai, India.

Minifie, B. (2012). Chocolate, cocoa and confectionery: science and technology. Springer Science \& Business Media.Prasetya A. Komponen Pembentuk Rasa Asam Pada Cokelat. http://4armita.wordpress.com. (in Indonesia)

Pérez, E., González, C., Vaillant, F., \& Lares, M. (2016). Stevia derivative and its potential uses in diabetic-directed foods. Review. Journal of Nutrients, 3(1), 1-20.

Sudarmadji, S., \& Suhardi, B. H. (2007). Analisis Bahan Makanan dan Pertanian. Penerbit Liberty, Yogyakarta.

Verruma-Bernardi, M., Lee, K., Liu, S. and Bordi Jr., P. (2014) Chocolate Milk with Sucrose and Stevia Preference by Pre- and Post-Menopausal Women. Food and Nutrition Sciences, 5, 1352-1358. doi: 10.4236/fns.2014.514147.

Widiantara T.2006. Peningkatan Karakteristik Produk Cokelat Olahan dengan Fortifikasi Inulin Soy Powder. Tesis. Universitas Pasundan. Bandung. 